\title{
Coupling between upper ocean layer variability and size-fractionated phytoplankton in a non-nutrient-limited environment
}

\author{
Pablo Sangràa ${ }^{1, *}$, Cristina García-Muñoz ${ }^{2}$, Carlos M. García ${ }^{3}$, \\ Ángeles Marrero-Díaz ${ }^{4}$, Cristina Sobrino ${ }^{5}$, Beatriz Mouriño-Carballido ${ }^{5}$, \\ Borja Aguiar-González ${ }^{4}$, Cristian Henríquez-Pastene ${ }^{6}$, Ángel Rodríguez-Santana ${ }^{4}$, \\ Luis M. Lubián ${ }^{2}$, Mónica Hernández-Arencibia ${ }^{4}$, Santiago Hernández-León ${ }^{1}$, \\ Elsa Vázquez ${ }^{5}$, Sheila N. Estrada-Allis ${ }^{4}$ \\ ${ }^{1}$ Instituto Universitario de Oceanografía y Cambio Global, Universidad de Las Palmas de Gran Canaria, \\ 35017 Las Palmas de Gran Canaria, Spain \\ ${ }^{2}$ Departamento de Ecología y Gestión Costera, Instituto de Ciencias Marinas de Andalucía (ICMAN-CSIC), \\ 11510 Puerto Real, Cádiz, Spain \\ ${ }^{3}$ Departamento de Biología, Facultad de Ciencias del Mar y Ambientales, Universidad de Cádiz, 11510 Puerto Real, Cádiz, Spain \\ ${ }^{4}$ Departamento de Física, Universidad de Las Palmas de Gran Canaria, 35017 Las Palmas de Gran Canaria, Spain \\ ${ }^{5}$ Departamento de Ecoloxía e Bioloxía Animal, Universidade de Vigo, 36200 Vigo, Pontevedra, Spain \\ ${ }^{6}$ Departamento de Geofísica, Universidad de Concepción, 160-C Concepción, Chile
}

\begin{abstract}
We describe the coupling between upper ocean layer variability and size-fractionated phytoplankton distribution in the non-nutrient-limited Bransfield Strait region (BS) of Antarctica. For this purpose we use hydrographic and size-fractionated chlorophyll a data from a transect that crossed 2 fronts and an eddy, together with data from 3 stations located in a deeply mixed region, the Antarctic Sound (AS). In the BS transect, small phytoplankton $(<20 \mu \mathrm{m}$ equivalent spherical diameter [ESD]) accounted for $80 \%$ of total chl $a$ and their distribution appeared to be linked to cross-frontal variability. On the deepening upper mixed layer (UML) sides of both fronts we observed a deep subducting column-like structure of small phytoplankton biomass. On the shoaling UML sides of both fronts, where there were signs of restratification, we observed a local shallow maximum of small phytoplankton biomass. We propose that this observed phytoplankton distribution may be a response to the development of frontal vertical circulation cells. In the deep, turbulent environment of the AS, larger phytoplankton (>20 $\mu \mathrm{m}$ ESD) accounted for $80 \%$ of total $\mathrm{chl} a$. The proportion of large phytoplankton increases as the depth of the upper mixed layer $\left(Z_{\mathrm{UML}}\right)$, and the corresponding rate of vertical mixing, increases. We hypothesize that this change in phytoplankton composition with varying $Z_{\mathrm{UML}}$ is related to the competition for light, and results from modification of the light regime caused by vertical mixing.
\end{abstract}

KEY WORDS: Physical-biological coupling - Mesoscale - Submesoscale - Vertical mixing · Phytoplankton composition · Antarctica

\section{INTRODUCTION}

The dynamics of phytoplankton in the upper ocean is linked to both the upper mixed layer (UML) and to mesoscale and submesoscale variability. The UML is the result of complex interactions between atmospheric forcing and this variability (e.g. Ferrari \& Boccaletti 2004). For example, mesoscale eddies may cause deepening or shoaling of the UML, thereby influencing the turbulent mixing and affecting the 
rate of vertical mixing of phytoplankton (e.g. Thompson et al. 2007). One major source of submesoscale variability is small filamentous fronts that originate at eddy boundaries or at mesoscale fronts. Intense vertical velocity associated with vertical circulation cells may cause the fronts to slump, resulting in restratification and enhancement of turbulent mixing (Thomas et al. 2008, D'Asaro et al. 2011). Vertical circulation cells related to mesoscale and submesoscale variability, mixing processes, and their interaction may modify the vertical exchanges of tracers and hence influence phytoplankton dynamics (e.g. Nagai et al. 2006, Klein \& Lapeyre 2009).

Vertical mixing may influence light availability, nutrient entrainment and uptake, zooplankton encounter probability, and settling velocity (e.g. Petersen et al. 1998, Huisman et al. 2002, Man \& Lazier 2006, Kiørboe 2007, Behrenfeld 2010). Turbulence is not always active in the UML and therefore it is important to distinguish between the terms UML and 'mixing layer'. The mixing layer is also a uniform density layer but where turbulence is active throughout (Brainerd \& Gregg 1995). The vertical extent of the upper mixing layer is particularly important for phytoplankton modulation by turbulence, because it determines the rate of vertical mixing of the cells. In a non-nutrient-limited environment it may be expected that this rate will essentially control the position and movement of the cells in the light gradient, as well as the zooplankton-phytoplankton encounters that can reduce/increase the grazing pressure.

Since the early Sverdrup (1953) critical depth hypothesis, many studies have used either the mixing layer depth or the upper mixed layer depth $\left(Z_{\mathrm{UML}}\right)$ as proxies for turbulence forcing. The effects of this forcing in less complex non-nutrient-limited environments are twofold: modulation of the population net growth rate, and modulation of the composition of the plankton community (e.g. Petersen et al. 1998, Huisman et al. 2004, Behrenfeld 2010). Hewes et al. (2008) studied the relationship between hydrographic properties, nutrients and phytoplankton biomass using data collected during a summer cruise in a region near the South Shetland Island that includes our study region (Fig. 1). In areas of high iron concentrations they observed an inverse relationship between $Z_{\mathrm{UML}}$ and total chl $a$, but with a very low coefficient of determination $\left(R^{2}=0.176\right)$. When climatological data for the region are considered (Hewes et al. 2009), this relationship is much more robust $\left(R^{2}=0.73\right)$. Climatological data analysis also showed that blooms in the region co-vary with shallow UML depths (e.g. Mitchell \& Holm-Hassen 1991, Hewes et

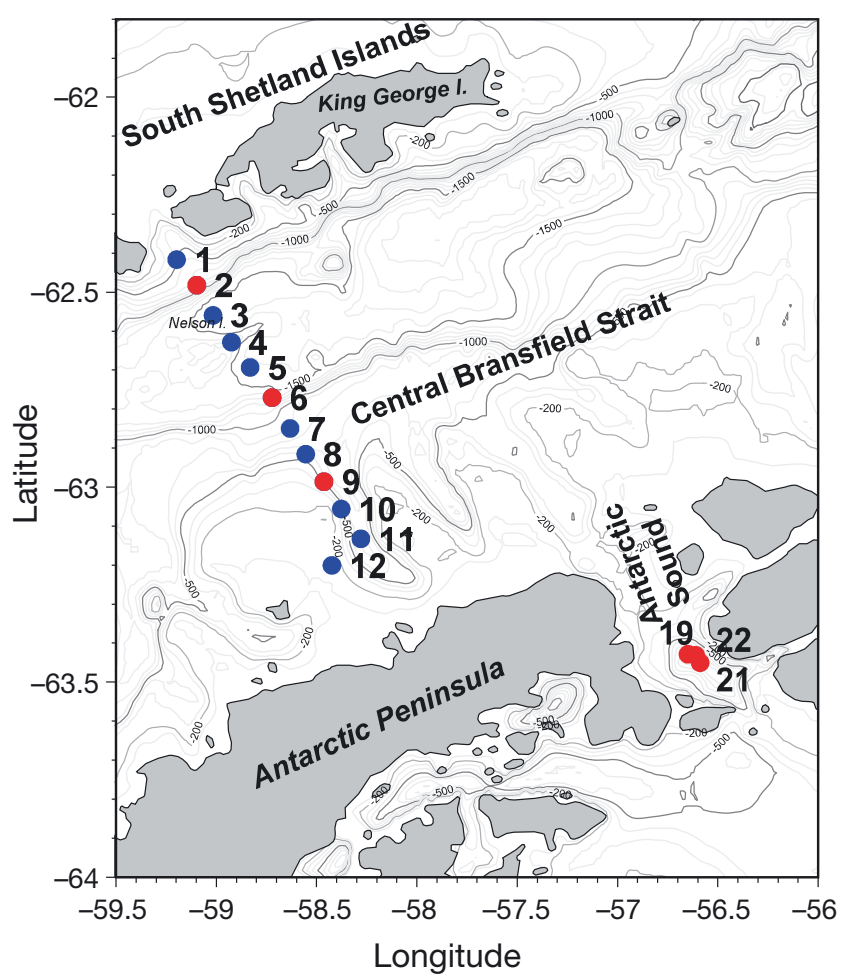

Fig. 1. Location of sample stations for the study of upper ocean layer variability and size-fractionated phytoplankton distribution in the Bransfield Strait (Stns 1 to 12) and Antartic Sound (Stns 19, 21 and 22), Antarctica. Blue dots: stations where standard measurements were taken; red dots: stations additionally sampled with a microstructure turbulence profiler. Gray lines are isobaths with a contour interval of $100 \mathrm{~m}$

al. 2009). Contrary to these observations, Holm-Hansen et al. (2004) did not observe any significant correlation between $Z_{\mathrm{UML}}$ and phytoplankton abundance in a much broader survey. They concluded that low iron concentrations are the major factor controlling phytoplankton biomass. Recent observations by Mendes et al. (2012) in the vicinity of James Ross Island (Weddell Sea) show bloom levels of phytoplankton $(\sim 5 \mathrm{mg}$ $\left.\mathrm{chl} a_{\mathrm{m}^{-3}}\right)$ in deep mixed layers $\left(Z_{\mathrm{UML}} \sim 80 \mathrm{~m}\right)$ and poorly stratified water.

Several studies in our surveyed region have also examined the possible relationship between the mixing layer depth/water stratification and phytoplankton composition (e.g. Kopczynska \& Ligowsky 1985, Kang \& Lee 1995, Kang et al. 2001, Mendes et al. 2012, 2013). Kopczynska \& Ligowsky (1985) first suggested a connection between variability of phytoplankton composition and water mass properties for this region. Kang \& Lee (1995) observed the dominance of nano-sized flagellates in the more stratified waters of the Bransfield Strait, whereas nano- and 
micro-sized diatoms dominate in the more homogeneous waters of Drake Passage. Recent results from 3 summer data collections by Mendes et al. (2013) showed that diatoms dominate in deeper mixed layer conditions whereas nano-sized cryptophytes dominate in more stratified conditions. Their February 2010 observations across Bransfield Strait are of particular interest because they almost coincided in time and location with the present study. As depicted in their Fig. 6, there is a clear correlation between the variability of the $Z_{\mathrm{UML}}$ and phytoplankton composition along the cited transect. For stratified environments $\left(Z_{\mathrm{UML}} \sim 15\right.$ to $25 \mathrm{~m}$ ) nano-sized phytoplankton dominated. In a homogeneous water column with a very deep mixed layer $\left(Z_{\mathrm{UML}}>160 \mathrm{~m}\right)$ diatoms dominated instead.

This study aimed to explore observationally how the distribution and composition of phytoplankton are connected with the variability of the ocean surface layer. The observations by Mendes et al. (2013), although made in the same area surveyed by us, were, however, mainly decoupled from the mesoscale variability, as their spatial resolution well exceeded the mean local first baroclinic Rossby radius of deformation (Rd) $(\sim 10 \mathrm{~km}$; Chelton et al. 1998). Therefore, these observations do not resolve the effects of mesoscale variability and their interaction with the UML on the plankton dynamics. In January 2010, during the mid-austral summer, an interdisciplinary survey was made over a region located near the South Shetland Island at mesoscale resolution (stations $\sim 9 \mathrm{~km}$ apart, Fig. 1). The general coupling between the mesoscale and phytoplankton distributions and their taxonomic composition has already been outlined in the study by García-Muñoz et al. (2013) from a more detailed biological perspective. In the present study we focused attention on the processes underlying this coupling. Particular emphasis was given to the Bransfield Strait region (Fig. 1), where distinct water masses meet and there is a rich mesoscale variability (Sangrà et al. 2011). Moreover nutrient concentrations in this southern region were above limiting thresholds for phytoplankton growth, both during this cruise and in past observations (Hewes et al. 2009, Teira et al. 2012). This allowed our analysis of the effects of the physical environment to focus on light rather than nutrient availability as the main factor affecting phytoplankton growth in conditions of vertical mixing. Both circumstances make the selected region suitable for the study of the coupling between ocean surface layer variability and phytoplankton dynamics.

\section{MATERIALS AND METHODS}

\section{Physical data collection}

Data were acquired during the interdisciplinary cruise COUPLING conducted in January 2010 on board RV 'Hespérides', during the austral midsummer near the South Shetland Islands. This survey formed part of the project COUPLING (Physical-biological coupling at the mesoscale range around the South Shetland Islands) of the Spanish Antarctic Program. For this study we selected 1 transect of 12 stations across the Central Bransfield Strait and 3 stations (Stns 19, 21 and 22) in the Antarctic Sound (Fig. 1). Distinct water mass compositions and rich mesoscale variability were the motivation for this selection. In order to resolve the mesoscale, stations were sampled every 5 nautical miles $(\sim 9 \mathrm{~km})$. The transect sampling can be viewed as quasi-synoptic as $<3$ d (8 to 11 January 2010) were required to complete the transect. At each station, vertical profiles of temperature, salinity and in situ fluorescence were obtained using a Seabird 911plus combined conductivity, temperature and depth sensor (CTD) with a Seapoint fluorescence sensor attached to a rosette system of 24 oceanographic 121 Niskin bottles. We also recorded microstructure profiles with a microstructure turbulence profiler (TurboMap; Wolk et al. 2002) at 3 stations of the transect (Stns 2, 6 and 9), and at the 3 stations (13 to 14 January 2010) in the Antarctic Sound (Fig. 1). Three casts were conducted at each station and data were depth averaged within $8 \mathrm{~m}$ bins. The dissipation rate of turbulent kinetic energy $\varepsilon$ was estimated from the measured vertical microstructure shear and derived from the shear variance by integrating the power spectrum of the velocity shear between length scales of $2 \mathrm{~cm}$ and half the Kolmogorov scale. A correction was made to recover the unresolved variance using the Nasmyth empirical spectrum (Oakey \& Elliott 1982).

As an indicator of turbulent mixing we computed the Thorpe scales (Thorpe 1977) from the CTD casts using a method analogous to those of Gargett \& Garner (2008). We first removed spikes in salinity, removed pressure reversal, and depth-averaged data at each half meter. Second, we sorted the density profiles in order to obtain statically stable profiles without inversions. We then calculated the Thorpe displacements as the vertical shifts of data points needed to achieve static stability. Finally the Thorpe scale was calculated from the root mean square of an ensemble of Thorpe displacements as computed at successive non-zero Thorpe displacements. 
$Z_{\mathrm{UML}}$ was inferred from CTD profiles using the Kara et al. (2000) algorithm. First, the potential density anomaly at $10 \mathrm{~m}$ is chosen as an initial reference density $\sigma_{\theta r e f}$. Second, a search is made of the potential density anomaly profile for regions of uniform potential density anomaly. These regions were defined as any pair of adjacent values where the potential density anomaly variation $\Delta \sigma_{\theta}$, corresponding to a change of potential temperature of $0.8^{\circ} \mathrm{C}$, was $<0.1$. If a uniform region is found, $\sigma_{\theta \text { ref }}$ is updated with the values corresponding to the shallower depth of the pair of profile points. This procedure is applied for every occurrence of pairs of points within the first uniform potential density anomaly region so that $\sigma_{\theta r e f}$ is that at the base of the mixing layer. Then, the mixing layer depth is the depth at which the potential density anomaly has changed by an absolute value of $\Delta \sigma_{\theta}$ from this reference value.

For each station a vertical light attenuation coefficient $k_{\mathrm{d}}\left(\mathrm{m}^{-1}\right)$ was calculated by measuring photosynthetically available radiation (PAR, wavelength $400-750 \mathrm{~nm}$ ) values at $1 \mathrm{~m}$ depth intervals in the water column with a hemispherical quantum sensor (CI PAR, Chelsea Instruments, relative spectral sensitivity flat to $+3 \%$ from 450 to $700 \mathrm{~nm}$ ). The euphotic layer depth $\left(Z_{\mathrm{EU}}\right)$ was defined as the depth at which the light intensity was attenuated to $1 \%$ of its value just below the surface, and was calculated as $Z_{\mathrm{EU}}=$ $\ln (0.01) / k_{\mathrm{d}}$. Values of $k_{\mathrm{d}}$ were calculated over the depth that PAR measurements are reliable as shown by Vaillaincourt et al. (2003).

Current velocities were measured continuously using a hull-mounted $75 \mathrm{KHz}$ acoustic Doppler current profiler (ADCP; Teledyne RD Instruments). We use broadband raw data with 2 min ensembles from the surface to $\sim 500 \mathrm{~m}$ depth with a bin size of $8 \mathrm{~m}$. Raw current velocity data were processed using the CODAS software package (Firing 1991); ship motions were removed. At each station in the Bransfield Strait we averaged the ensembles along the first 10 min and last 10 min of the CTD-rosette complete cast, whereas for the Antarctic Sound we used continuously recorded data along the $30 \mathrm{~h}$ sampling interval. We decided not to remove the signal of the barotropic tide as the tidal model used predicts that it is very low in this area (Padman et al. 2002).

\section{Chlorophyll a data}

Chl a concentrations were determined fluorometrically; $250 \mathrm{ml}$ water samples were sequentially filtered through 20,2 and $0.2 \mu \mathrm{m}$ polycarbonate membrane filters and pigments were extracted overnight in $90 \%$ acetone at $-20^{\circ} \mathrm{C}$. We discriminate between small and large phytoplankton as a function of their corresponding size-fractionated chl a concentrations resulting from the above sequential filters. Small phytoplankton includes concentrations for size fractions $<20 \mu \mathrm{m}(0.2$ to $20 \mu \mathrm{m})$ and large phytoplankton concentrations for size fractions $>20 \mu \mathrm{m}$. Fluorescence was measured using a Turner TD-700 fluorometer which had been calibrated with pure chl a following UNESCO (1994) standard protocol. To calibrate fluorescence measurements we followed Cuttelod \& Hervé (2010). Fluorescence values used for calibration were recorded at the closing of each sampling bottle used for $\mathrm{chl}$ a determination operated from the deck computer. The average value of fluorescence in the layer 350 to $400 \mathrm{~m}$ was thus first subtracted at all depths, to produce the depth corrected fluorescence. Then we obtained the following linear regression relation that was used to transform depth-corrected relative fluorescence units $(\mathrm{FC})$ to $\mathrm{chl} \mathrm{a} \mathrm{(mg} \mathrm{chl} a \mathrm{~m}^{-3}$ ) for this cruise: chl $a=0.596 \mathrm{FC}+0.064, \mathrm{n}=118, \mathrm{R}^{2}=0.734$. As fluorometer data were not reliable near the surface, when obtaining the vertical section of total chl a from the fluorometer calibrated data we used the values of extracted total-chlorophyll for the near surface layers $(5,10$ and $20 \mathrm{~m})$.

\section{RESULTS AND DISCUSSION}

\section{Mesoscale variability}

Fig. 2 shows the distribution of isopycnals along the transect crossing the Bransfield Strait (Fig. 1). We observed the same water masses and mesoscale structures as those previously reported for the region by Sangrà et al. (2011). The main water masses are the relatively warm and fresh Transitional Zonal Water with Bellingshausen influence (TBW) that enters the Strait from the west and the relatively cold and salty Transitional Zonal Water with Weddell Sea influence (TWW) that inflows from the Weddell Sea and occupies the main body of the Strait (Sangrà et al. 2011). Mesoscale variability is mainly represented by the Bransfield Front, an anticyclonic eddy, and the Peninsula Front. These structures are very closely related and form part of what Sangrà et al. (2011) named the Bransfield Current System (BCS). In Fig. 2 we can clearly recognize the signal of the Bransfield Front by the steeply tilted isopycnals at the subsurface layers between Stns 1 and 3. The front extends until $\sim 300 \mathrm{~m}$, which is in the range of TWW. Current velocities from 


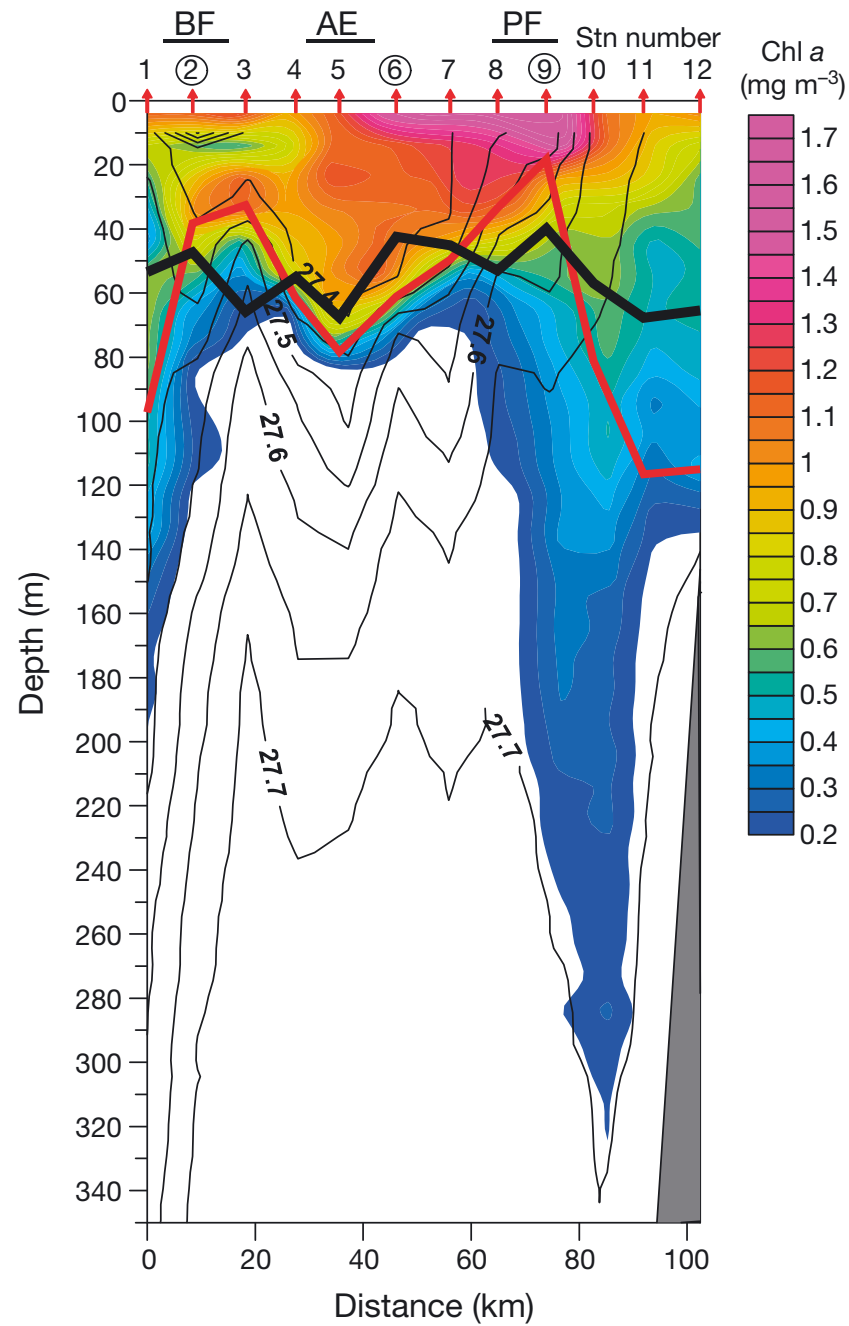

Fig. 2. Mesoscale variability in the Bransfield Strait (Stns 1 to 12): Thin black lines are isopycnals (potential density anomaly $\sigma_{\theta}, \mathrm{kg} \mathrm{m}^{-3}$ ); the color filled contour plot shows total chl $a$ $\left(\mathrm{mg} \mathrm{m}^{-3}\right)$ calculated from fluorometer calibrated data (color filled contour plot); the bold black line shows the euphotic layer depth $\left(Z_{\mathrm{EU}}\right)$ and bold red line shows the upper mixed layer depth $\left(Z_{\mathrm{UML}}\right)$. Circled stations on the top axis indicate Stns 2, 6 and 9 where turbulence profiles were recorded. The locations of the Bransfield Front (BF), the anticyclonic eddy (AE) and the Peninsula Front (PF) are indicated on the top axis. The bottom topography is indicated by the shaded grey area at the right lower corner

the ADCP indicate a jet-like structure that is associated with the Bransfield Current; its axis is centered at Stn 2, where the current velocity can reach up to $0.4 \mathrm{~m}$ $\mathrm{s}^{-1}$. This current is the major component that drives the BCS, transporting TBW along the slope of the South Shetland Islands. In Fig. 2 we can also identify the signature of an anticyclonic eddy through the deepening of the isopycnals between Stns 3 and 6 just south of the Bransfield Front. The signal of the eddy is visible until $\sim 240 \mathrm{~m}$ depth within the TBW range. Due to geostrophic adjustment there is a deepening of the isopycnals at the center of the eddy that induces an increase of $Z_{\mathrm{UML}}$ between Stns 3 and 6. Eddy sampling took $28 \mathrm{~h}$; during this period it is unlikely that the eddy displacement was greater than $10 \mathrm{~km}$ and thus its sampling can be considered to be quasi-synoptic. This is supported by the fact that westward shelf-advection speeds of the eddies at high latitudes are very low (Chelton et al. 2007); advection by the mean flow can be discounted as outside the Bransfield Front it does not exceed $0.1 \mathrm{~m} \mathrm{~s}^{-1}$ (Sangrà et al. 2011). Finally, close to the Antarctic Peninsula, we can recognize the signal of a shallow frontal region through the steeply tilted isopycnals between Stns 7 and 11 that Sangrà et al. (2011) named the Peninsula Front. TBW and TWW converge at the surface of the Peninsula Front. The above structures have been detected in all mesoscale resolution surveys of the region and, hence, they can be considered as permanent features of the circulation of this region during the austral summer (Sangrà et al. 2011).

From the combined distribution of fluorometer calibrated total chl $a$ and isopycnals show in Fig. 2, we can extract signs of relatively strong subduction regions at both fronts. These regions are indicated by rather high values of total chl a well below $Z_{\mathrm{UML}}$, and the euphotic layer forming deep column-like structures. At the Bransfield Front, values of total chl a > $0.2 \mathrm{mg} \mathrm{m}^{-3}$ were observed down to $180 \mathrm{~m}$ depth, indicating phytoplankton subduction on the light (anticyclonic) side of the front at Stn 1 (Fig. 2). At the Peninsula Front heavy (cyclonic) side (between Stns 9 and 11) there is also clearly evidence of subducting phytoplankton. The distribution of total chl a has a column-like structure between Stns 9 and 11, that is subducted down as far as $300 \mathrm{~m}$ at Stn 10 (Fig. 2). Models and observations (e.g. Nagai et al. 2006, Pallàs-Sanz et al. 2010) have related these frontal subduction regions with the descending part of vertical circulation cells linked to ageostrophic secondary circulation of the front.

Although our data set is too incomplete (i.e. 2dimensional and with insufficient resolution at both fronts) to diagnose the vertical circulation, the occurrence of deep chl a columns supports, at least qualitatively, a downward motion at one side of both fronts. Observations in other frontal regions (e.g. Pollard \& Regier 1992, Pallàs-Sanz et al. 2010, Thomas \& Joyce 2010), show that the subducting region on one side of a front is accompanied by an upwelling region on the other side. On the upwelling side of the front restratification may take place due to slumping of the isopycnals induced by the ascending water (Nagai et al. 2006, Thomas et al. 2008). At the heavy (cyclonic) 
side of the Bransfield Front (between Stns 2 and 3) there are signs of restratification evidenced by the squeezing of isopycnals at the depth range 30 to $60 \mathrm{~m}$ and by the slumping of the 2 nearest surface isopycnals' accompanied by a shoaling of the UML. On the light (anticyclonic) side of the Peninsula Front, between Stns 8 and 9, the UML also shoals, indicating restratification. This shoaling is due to the decreased tilt of the 27.5 and $27.55 \mathrm{~kg} \mathrm{~m}^{-3}$ isopycnals near the surface (20 to $40 \mathrm{~m}$ ) and the opposing tilt of the 27.6 and $27.65 \mathrm{~kg} \mathrm{~m}^{-3}$ isopycnals at deeper layers (60 to $80 \mathrm{~m}$ ). Although the restratification observed on the heavy (cyclonic) side of the Bransfield Front and on the light (anticyclonic) side of the Peninsula Front may be due to internal motions, the occurrence of an upwelling region accompanying the subducting region should not be disregarded.

\section{Upper mixed layer (UML) variability}

As shown in Fig. 2, the $Z_{\mathrm{UML}}$ is modulated by the presence of mesoscale structures. It is deeper on the light (anticyclonic) side of the Bransfield Front at Stn 1, in the center of the eddy (Stns 4 and 5), on the heavy (cyclonic) side of the Peninsula Front (Stns 10 and 11), and at TWW (Stn 12), coinciding with geostrophically depressed isopycnals and/or with the subducting regions. At Stn 12 the $Z_{\mathrm{UML}}$ reaches the bottom because the whole water column is occupied by TWW which is homogeneous. The $Z_{\mathrm{UML}}$ is shallower at the axis and at the heavy side of the Bransfield Front (between Stns 2 and 3) and at the axis and the light side of the Peninsula Front (Stns 7, 8 and 9). It is important to investigate whether turbulent mixing is active over the whole depth range of the observed UMLs and thus if the UMLs are actually mixing layers. Regarding this question, the $\varepsilon$ profile at Stn 6 located inside the eddy shows a turbulent upper mixing layer throughout the depth range of the UML, where values of $\varepsilon$ are maximum (Fig. 3b). If we choose the depth of this mixing layer as the depth where the value of $\varepsilon$ drops by one order of magnitude (Brainerd \& Gregg 1995), this depth coincides approximately with the $Z_{\mathrm{UML}}$ as indicated by the corresponding density profile
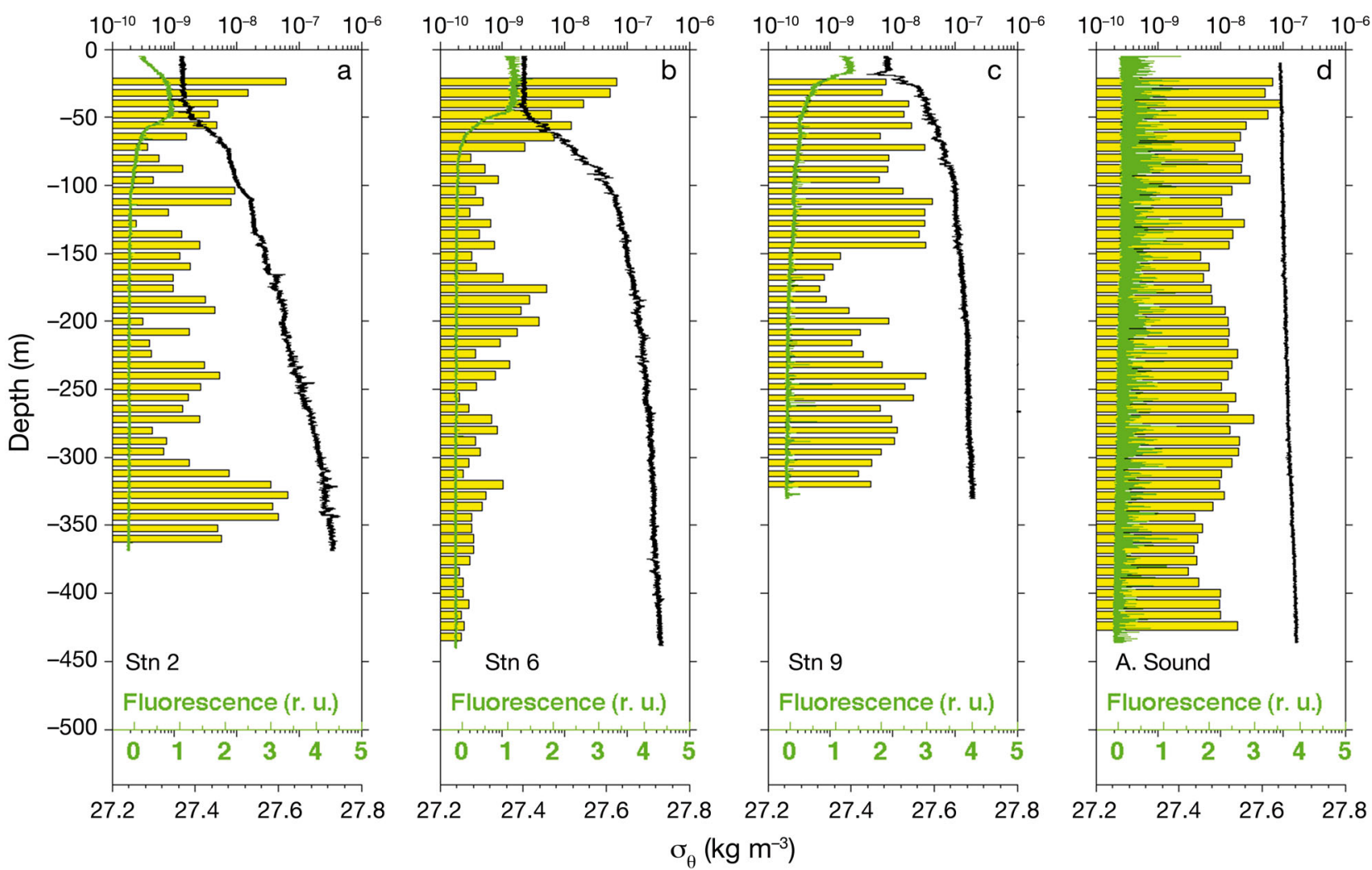

Fig. 3. Averaged vertical profiles of kinetic energy dissipation rate $\varepsilon$ (bars, $\mathrm{W} \mathrm{kg}^{-1}$ ), potential density anomaly $\sigma_{\theta}$ (black lines, $\mathrm{kg} \mathrm{m}^{-3}$ ), and fluorescence (green lines, relative units) as obtained from microstructure turbulence profilers at (a) the Bransfield Front (Stn 2), (b) the anticyclonic eddy (Stn 6), (c) the Peninsula Front (Stn 9) and (d) the Antarctic Sound (based on average values measured at Stns 19, 21 and 22) 
(Fig. 3b). The profile for Stn 2 also shows a maximum of $\varepsilon$ in the UML portion of the water column (Fig. 3a). Vertical profiles of $\varepsilon$ show a deeper mixing layer at the Peninsula Front axis (Stn 9) when compared with those at the Bransfield Front axis (Stn 2) and at the eddy (Stn 6) (Fig. 3a,b,c). This deepreaching mixing may be related to frontal instabilities that may enhance mixing as observed by D'Asaro et al. (2011) in a small submesoscale front. Stn 9 was located at the mouth of a submarine canyon. This complex bathymetry may favor the generation of internal motion that could be also responsible for the observed deep mixing.

Unfortunately we do not have direct measurements of turbulence from all the stations. An indirect approach to infer whether the mixed layer corresponds to an active turbulent layer is to quantify the Thorpe scale (Thorpe 1977). The Thorpe scale measures the inversions in a vertical density profile (e.g. Gargett \& Garner 2008). Thorpe (1977) related these inversions to the 3-dimensional turbulent eddy field overturning. Therefore, the appearance of the inversion in a vertical density profile is an indicator of turbulent mixing (Gargett \& Garner 2008). Fig. 4 shows the distribution of the Thorpe scale along the Bransfield Strait transect. In general, the $Z_{\mathrm{UML}}$ effectively matches the base of an upper active turbulent layer where inversions are frequent. The most active turbulent layer is observed within the UML of the anticyclonic eddy between Stns 3 and 6. Another active turbulent region corresponds to Stns 10, 11 and 12, where the inversion reaches the $Z_{\mathrm{UML}}$ indicating that the whole UML is actually an active turbulent layer. Although intermittent, the density profile of Stn 1 also shows inversions down to the $Z_{\mathrm{UML}}$, indicating turbulent activity at the depth range of the UML. At the axis of the Peninsula Front (Stn 9) there are intense inversions below the $\mathrm{UML}_{\text {; }}$ this indicates that the UML and the mixing layer are decoupled, as the turbulence profiles further point out.

\section{Antarctic Sound turbulent environment}

Fig. 3d shows mean profiles of density, fluorescence and $\varepsilon$ as obtained from the microstructure turbulence profiler in the Antarctic Sound. Notice the higher levels of turbulence throughout the water column in comparison with the Bransfield Strait profiles. In fact the mean value of the 9 profiles recorded in the Antarctic Sound for the depth range 20 to $100 \mathrm{~m}, \varepsilon=$ $5.73 \times 10^{-7} \mathrm{~W} \mathrm{~kg}^{-1}$, was $\sim 5$-fold higher than those recorded along the Bransfield Strait transect, $\varepsilon=$

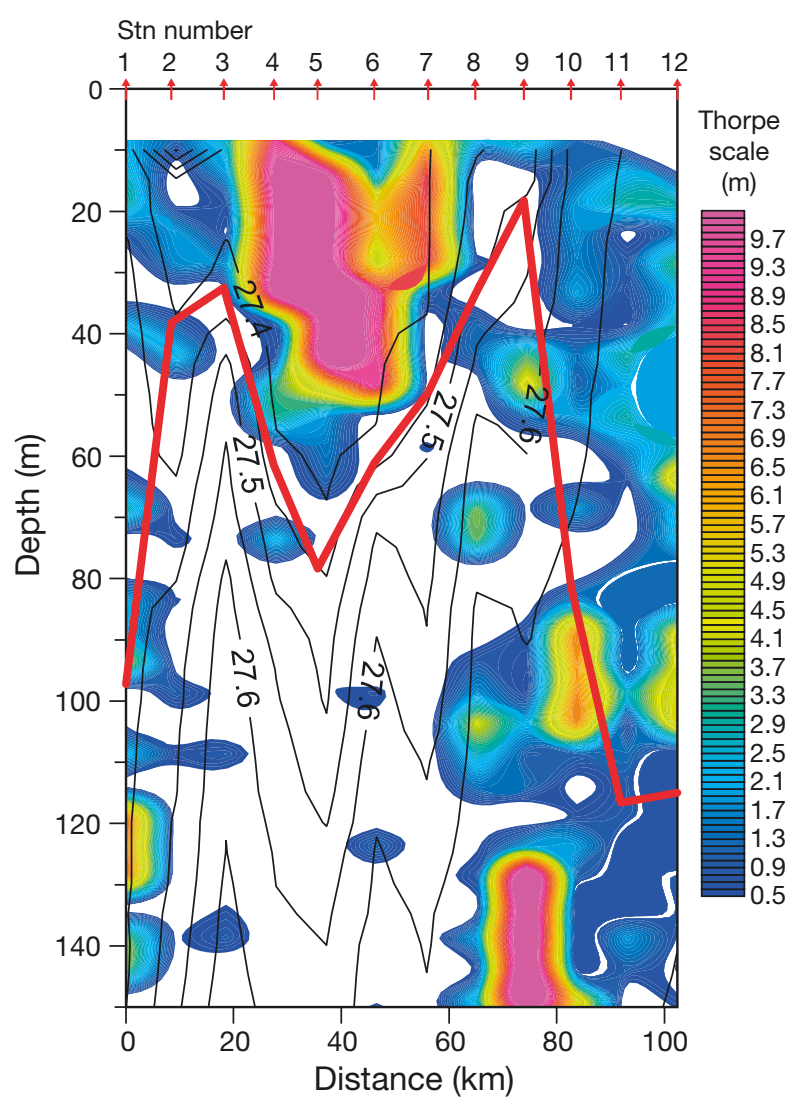

Fig. 4. Thorpe scale distribution (filled color contour plot) in the Bransfield Strait. Thorpe scale units are in meters and provide a measure of vertical overturning and thus an indicator for turbulent mixing. Turbulent mixing will be more active for large Thorpe values and less active for low Thorpe values. Note that the largest values are observed in the UML, coinciding with the largest values of $\varepsilon$ (see Fig. 3). See Fig. 2 legend for explanation of superimposed black and red lines

$1.22 \times 10^{-7} \mathrm{~W} \mathrm{~kg}^{-1}$. Antarctic Sound density profiles were homogeneous over the full depth range (Fig. 3d), and composed of Weddell Sea Shelf Water (WSSW). As TWW (potential temperature, $\theta=-1.30$ to $-0.50^{\circ} \mathrm{C}$, salinity, $\mathrm{S}=34.37$ to 34.5 ) is a modification of WSSW $\left(\theta=-1.73\right.$ to $-0.93^{\circ} \mathrm{C}, \mathrm{S}=34.37$ to 34.5$)$, the 2 water masses are not very distinct; they are cold, salty and homogeneous, with WSSW being slightly colder. Therefore the water mass properties are very similar south from the axis of the Peninsula Front and at the Antarctic Sound. Because the density profiles are homogeneous, instead of defining a $Z_{\mathrm{UML}}$ we computed the mixing layer depths as the depth where $\varepsilon$ is reduced by an order of magnitude: hence $350 \mathrm{~m}$ for Stn 19, $220 \mathrm{~m}$ for Stn 21, and $320 \mathrm{~m}$ for Stn 22. Notice that those mixing layer depths are more than 3 fold higher than the observed mean $Z_{\mathrm{UML}}(60 \mathrm{~m})$ at the Bransfield Strait. 


\section{Coupling total chl $a$ with mesoscale variability and mixing}

Maximum values of total chl $a$, as obtained from the fluorometer calibrated data (Fig. 2b), were observed near the surface on the light (anticyclonic) side and at the axis of the Peninsula Front (Stns 7, 8, and 9), and at the edge of the Anticyclonic Eddy (Stn 6). At the Peninsula Front stations these maxima coincide with the shallowest UML $(54,34$, and $18 \mathrm{~m}$ respectively) and are thus located on the restratified side of the front. From this maximum, the phytoplankton is subducted and mixed within the heavy (cyclonic) side of the front (between Stns 9 and 11). This subducting region acts as a sink for the cells that are transported to the deep ocean interior down to at least $300 \mathrm{~m}$. Therefore the cross-frontal distribution of total chl $a$ is asymmetric, with a shallow local maximum on the restratified side of the front and a deep column-like structure on the subducting side.

At TWW (Stn 12), total chl a distribution is also diluted over the whole water column, probably due to a high rate of vertical mixing as suggested by an UML reaching the bottom $(115 \mathrm{~m})$, and by the high density of inversions (Fig. 4). As shown in Fig. 2, the maximum at the Peninsula Front diffuses towards the eddy, attenuating its intensity and diluting in the UML. This suggests that the eddy entrains the phytoplankton from the Peninsula Front source, although in situ net growth should not be disregarded. The entrained phytoplankton will be subject to mixing and accumulate at the eddy UML. This can explain the relatively high values of total chl $a$ at subsurface levels $(30$ to $60 \mathrm{~m})$ inside the eddy. The largest density inversions were observed at the eddy, suggesting strong mixing (Fig. 4). This is confirmed by direct measurements of turbulence at Stn 6 (Fig. 3b).

At the axis and at the heavy (cyclonic) side of the Bransfield Front (Stns 2 and 3) a relative maximum of total chl $a$ at the base of the UML was observed but it had lower concentrations than those at the Peninsula Front. As for the case of the Peninsula Front, this coincides with the restratified side of the front evidenced by a local minimum of the $Z_{\mathrm{UML}}$. On the light (anticyclonic) side located at Stn 1, the concentration of total chl $a$ is again diluted in the water column, coinciding with a deep UML. As already mentioned, significant values of total chl a were observed until $180 \mathrm{~m}$, well below the $Z_{\mathrm{UML}}$ and $Z_{\mathrm{EU}}$, indicating subduction. Similarly to the case of the heavy (cyclonic) side of the Peninsula Front, this subduction and high rate of vertical mixing may be responsible for the observed total chl a dilution throughout the water column. Again, as was the case for the Peninsula Front, the cross-frontal distribution of total chl a was asymmetric, with a deep column-like structure indicating subduction on one side, and a shallow local maximum on the restratified side.

A plausible explanation for this asymmetric distribution may be related to the occurrence of vertical circulation cells as observed in other frontal regions (e.g. Pallàs-Sanz et al. 2010) as previously suggested. The descending part of these cells may cause the subducting, column-like structure of chl $a$ in the deep UML part of the fronts. At the restratified part of the fronts, the shallow local maximum may be related to the ascending part of the vertical cell that will transport phytoplankton cell to the surface where higher light levels will increase their net growth rate. Other plausible mechanisms that may explain the observed local maxima on the sides of the fronts are the occurrence of a confluent flow and/or the advection of phytoplankton from an upstream source.

\section{Preference of large plankton for well-mixed environments}

When correlating phytoplankton size fraction variability with the physical environment, the first noticeable point is that in the relatively high turbulent environment of the Antarctic Sound large phytoplankton dominate, whereas in the low turbulent region of the Bransfield Strait small phytoplankton dominate (Fig. 5). In the Antarctic Sound, where the upper turbulent active layer is very deep (>300 m, Fig. 3d), the chl a profiles are homogeneous, with a mean value of $1.8 \mathrm{mg} \mathrm{m}^{-3}$ for larger phytoplankton and one order of magnitude less, $0.3 \mathrm{mg} \mathrm{m}^{-3}$, for small phytoplankton. In the Bransfield Strait (lower average turbulence) the picture is reversed. There, the maximum values for small phytoplankton largely exceed $1 \mathrm{mg} \mathrm{m}^{-3}$ whereas the values for large phytoplankton do not exceed $0.5 \mathrm{mg} \mathrm{m}^{-3}$ (Fig. 5a,b). García-Muñoz et al. (2013), using Flow-CAM and CHEMTAX software, observed that the nanophytoplankton size range is the most abundant along the Bransfield Strait transect. It is mainly composed of small diatoms followed by haptophytes, prasinophytes and cryptophytes. At the Antarctic Sound, they observed that phytoplankton is largely composed of microplanktonic diatoms, mainly Thalassiosira sp. (García-Muñoz et al. 2013).

The general pattern described above suggests that large phytoplankton have a preference for those environments where the rate of vertical mixing is 

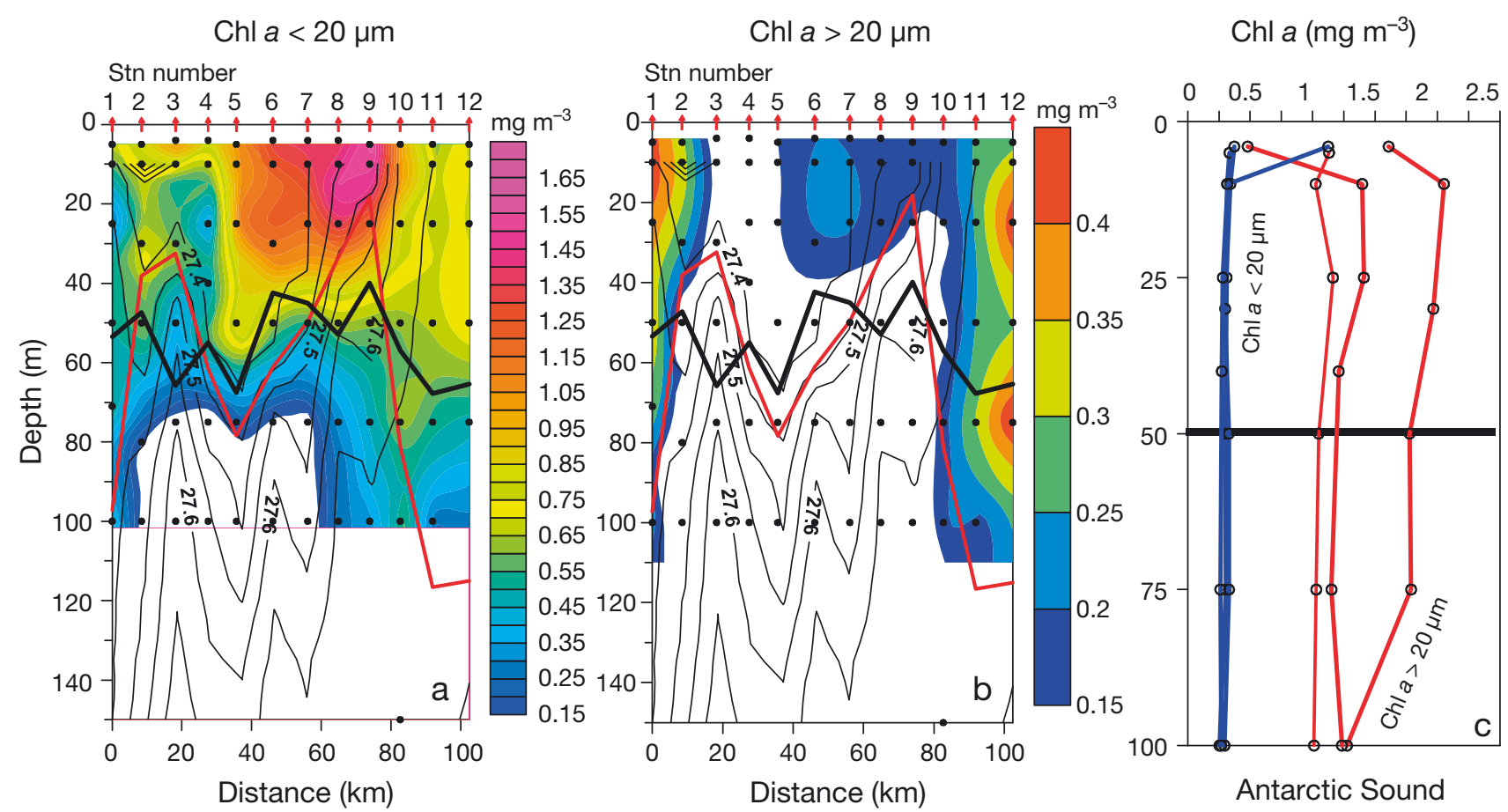

Fig. 5. Distributions of (a) small phytoplankton (chl $a<20 \mu \mathrm{m}$ equivalent spherical diameter [ESD]) and (b) large phytoplankton (chl $a>20 \mu \mathrm{m}$ ESD) in the Bransfield Strait (filled contour plots). See Fig. 2 legend for explanation of superimposed black and red lines. (c) Depth profiles of small (blue) and large (red) phytoplankton at the Antarctic Sound stations. The bold black line shows the euphotic layer depth $\left(Z_{\mathrm{EU}}\right)$

high, with very deep active turbulent upper layers such as those we observed at the Antarctic Sound stations. In this regard, if we inspect in more detail the Bransfield Strait section corresponding to the large phytoplankton (Fig. 5b) we can appreciate that, except for the near surface at Stn 2, clearly higher $\left(>0.25 \mathrm{mg} \mathrm{m}^{-3}\right)$ concentrations of large phytoplankton chl $a$ are found only at those stations coinciding with the deepest UMLs. This is the case of the light side of the Bransfield Front (Stn 1, $Z_{\mathrm{UML}}=91 \mathrm{~m}$ ), the heavy side of the Peninsula Front (Stn 11, $Z_{\mathrm{UML}}=$ $117 \mathrm{~m}$ ) and the TWW (Stn 12, $Z_{\mathrm{UML}}=115 \mathrm{~m}$ ). The Thorpe scale distributions at these stations indicates that the UML coincides with an active turbulent upper layer (Fig. 4), suggesting a high rate of vertical mixing. Therefore, a close inspection of the Bransfield Strait transect supports the above hypothesis concerning the preference of large phytoplankton for those environments where the rate of vertical mixing associated with deep UMLs is high. In contrast to the large phytoplankton distribution, size-fractionated chl a for small phytoplankton shows appreciable values $\left(>0.25 \mathrm{mg} \mathrm{m}^{-3}\right.$ ) all along the Bransfield Strait transect. As the phytoplankton are mainly composed of small phytoplankton $(80 \%)$ in this transect, their distribution mirrors the distribution for total chl $a$
(Fig. 2b). Thus the phytoplankton distribution responds to the same physical forcing as suggested above for total chl $a$, which is mainly coupled with mesoscale structure variability.

\section{Phytoplankton composition and $Z_{\mathrm{UML}}$ variability}

The above observations of size-fractionated $\mathrm{chl} a$ distribution suggest a covariance between large phytoplankton and the $Z_{\mathrm{UML}}$, and hence a relationship between this component and the rate of vertical mixing. To explore this, in Fig. 6 we plotted the percentage of large phytoplankton versus $Z_{\mathrm{UML}}$ for all our stations. Fig. 6 also shows the mean values of $\varepsilon$ for the Bransfield Strait and Antarctic Sound regions.

There is a clear linear relationship $\left(\mathrm{R}^{2}=0.86\right)$ between the $Z_{\mathrm{UML}} /$ mixing layer depth and the percentage of large phytoplankton (Fig. 6), indicating that the proportion of large phytoplankton increases with the deepening of the $Z_{\mathrm{UML}}$. For the shallowest $Z_{\mathrm{UML}}$ as is the case on the light side of the Peninsula Front (Stns 8 and 9) and the edge of the Bransfield Front (Stn 3), the percentage of large phytoplankton is less than $15 \%$. In those stations of the Bransfield Strait where the $Z_{\mathrm{UML}}$ is deep and well below the $Z_{\mathrm{EU}}$, as is 


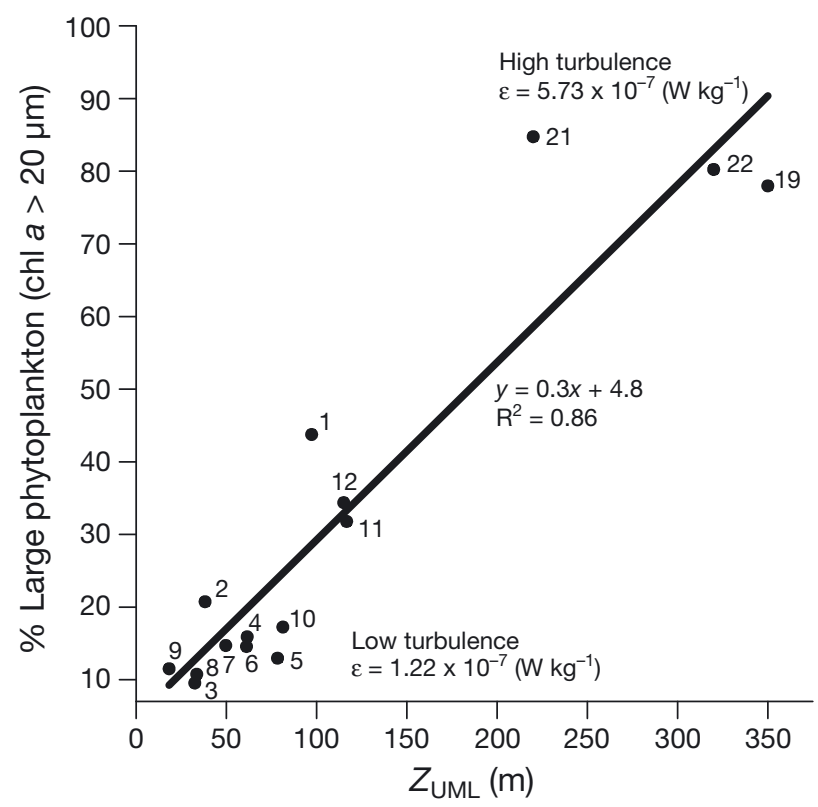

Fig. 6. Large phytoplankton ( $\mathrm{chl} a>20 \mu \mathrm{m}$ ) as a percentage of total extracted chl a integrated down to $100 \mathrm{~m}$ in relation to the depth of the upper mixed layer $\left(Z_{\mathrm{UML}}\right)$. Numbered dots show results for each station. Mean values of the kinetic energy dissipation rate $\varepsilon$ for the relatively low turbulence environment of the Bransfield Strait (Stns 1 to 12) and for the relatively high turbulence environment of the Antarctic Sound (Stns 19, 21 and 22) are also indicated

the case for Stns 1, 11 and 12, the percentage of large phytoplankton doubles, reaching values greater than $30 \%$ of the total chl a. As already mentioned, the Thorpe scale distribution indicates that turbulence is active throughout the $Z_{\mathrm{UML}}$. At the Antarctic Sound stations, where the upper active turbulent layer is 3 to 4 -fold deeper than the mean $\mathrm{Z}_{\mathrm{UML}}$ at the Bransfield stations, the proportions of large and small phytoplankton are reversed, with large phytoplankton accounting for about $80 \%$ of the total. The large phytoplankton biomass in terms of depth-integrated chl a concentration down to $100 \mathrm{~m}\left(\sim 130 \mathrm{mg} \mathrm{m}^{-2}\right)$ is one order of magnitude greater than the average biomass at the Bransfield Strait stations $\left(\sim 14 \mathrm{mg} \mathrm{m}^{-2}\right)$. Recall that $\varepsilon$ in the first $100 \mathrm{~m}$ and thus the level of turbulence of the Antarctic Sound stations was about 5-fold higher than at Bransfield Strait stations (Stns 2, 6 , and 9). This covariance of the $Z_{\mathrm{UML}}$ and the percentage of large phytoplankton reinforces the hypothesis that this size fraction has a preference for those physical environments where the upper turbulent layer is deep and, hence, where the rate of vertical mixing is high. Therefore it is also suggested that the variability of the rate of vertical mixing modulates the phytoplankton composition.
One may argue that the increase of large phytoplankton biomass at the Antarctic Sound (Stns 19, 21 and 22) may be due to its advection from an upstream source. However this scenario is unlikely as our ADCP data indicates that during the sampling of the Antarctic Sound stations there was a mean inflow of $\sim 0.2 \mathrm{~m} \mathrm{~s}^{-1}$ entering from the Bransfield Strait, where large phytoplankton biomass was very low. Although our ADCP records are only $30 \mathrm{~h}$ long, ADCP climatological observations of Savidge \& Amft (2009) also show this inflow from the Bransfield Strait for the summer period.

As models predict (e.g. Huisman et al. 2002), we propose 2 mechanisms for explaining the observed high biomass of large phytoplankton in deep wellmixed layers. The first mechanism is that large phytoplankton have a moderate sinking rate, so that a minimum level of turbulence is necessary to maintain cells for long enough in the water column to have a positive net growth (Huisman et al. 2002). The second mechanism is based on the assumption that growth rates in the upper part of the water column exceed vertical mixing (Huisman et al. 2002). For this we assume that the rate of vertical mixing does not exceed a critical level. The order of magnitude of our turbulence measurements for high turbulent areas $\left(\varepsilon \sim 10^{-7} \mathrm{~W} \mathrm{~kg}^{-1}\right)$ may be considered as an intermediate level of turbulence when compared to other observations of UMLs where values of eusally range between $\sim 10^{-9}$ and $<10^{-2} \mathrm{~W} \mathrm{~kg}^{-1}$ (Lozovatsky et al. 2005).

We also propose that the observed shift in composition could be associated with the competition for light, and results from the modification of the light regime by vertical mixing. The above mechanisms show that large phytoplankton can survive in turbulent environments but do not explain why they gradually dominate over smaller phytoplankton as the rate of vertical mixing increases. We suggest that large phytoplankton species gain a competitive advantage over small plankton species by exploiting fluctuating and low light regimes that emerge in environments with high rates of vertical mixing. This agrees with models that predict a shift in phytoplankton composition when vertical mixing varies; species with lower critical light intensity levels dominate when the rate of vertical mixing is high (e.g. Elliot et al. 2002, Huisman et al. 1999, 2004). Critical light intensity is defined as the light intensity at the bottom of a well-mixed water column at which phytoplankton can just survive and is species specific (e.g. Weissing \& Huisman 1994, Huisman et al. 1999, Passarge et al. 2006). It has 
also been reported that Antarctic diatoms actively utilize the photoprotective xanthophyll cycle for heat dissipation, minimizing photoinhibition (Kropuenske et al. 2009, Van de Poll et al. 2011). As reported in the literature, Thalassiosira sp., which in this case is one of the main taxa composing large phytoplankton, exhibits one of the largest ranges for the light intensity minimum and maximum growth rates (Richardson et al. 1983). This suggests a lower critical light level compared to dominant small phytoplankton species. It also suggests that this diatom may maintain optimal photosynthetic rates in the deep UML where variability in the light environment is significantly high for phytoplankton (Lavaud et al. 2007). There are observations in other oceanic areas that indicate that the deep UML may create a niche for large diatoms thanks to the aforementioned superior capacity to exploit fluctuating light and low irradiance regimes (e.g. Goldman \& McGillicuddy 2003, Thompson et al. 2007).

In conclusion, our observations suggest that phytoplankton in the Bransfield Strait region do not react as a whole to physical forcing; instead, different selective responses occurs depending on the physical process involved. Small phytoplankton distributions strongly correlate with the presence of mesoscale structures. An asymmetric distribution was observed across the 2 frontal regions. A deep column-like structure was observed on the deepening $Z_{\mathrm{UML}}$ sides of the fronts indicating subduction. A local shallow maximum was observed on the other sides, coinciding with restratification and the accompanying shoaling of the UML. Large phytoplankton strongly correlate with the rate of vertical mixing with a preference for environments where this rate is high and thus dominant in the highly turbulent environment of the Antarctic Sound. On the other hand, in the Bransfield Strait, where mean vertical mixing is low, their proportion is very low except in those stations where vertical mixing is clearly above the mean.

Acknowledgements. We express our gratitude to the technical staff and crew of RV Hespérides for supporting our work at sea. This work was supported by the Spanish government through project COUPLING (CTM2008-06343-CO2-01). The authors are grateful to Celia Marrasé and Francesc Peters from the Institut de Ciències del Mar-CSIC for providing useful suggestions and comments. C.G-M. was supported by a predoctoral fellowship from the Spanish Council for Scientific Research (CSIC), JAE-Predoc 2009. B.M.-C was supported by the Ramón y Cajal program from the Spanish Ministry of Education and Science.

\section{LITERATURE CITED}

Behrenfeld MJ (2010) Abandoning Sverdrup's Critical Depth Hypothesis on phytoplankton blooms. Ecology 91: 977-989

Brainerd K, Gregg M (1995) Surface mixed and mixing layer depths. Deep-Sea Res I 42:1521-1543

Chelton DB, Deszoeke RA, Schlax MG, Naggar K, Stwertz N (1998) Geographical variability of the first baroclinic Rossby radius of deformation. J Phys Oceanogr 28:433-460

Chelton DB, Schlax MG, Samelson RM, de Szoeke RA (2007) Global observations of large oceanic eddies. Geophys Res Lett 34:L15606, doi:10.1029/2007GL030812

Cuttelod A, Hervé C (2010) ALMOFRONT 2 cruise in Alboran sea: chlorophyll fluorescence calibration. J Oceanogr Research Data 3:6-11

D'Asaro E, Lee C, Rainville L, Harcourt R, Thomas LN (2011) Enhanced turbulence and energy dissipation at ocean fronts. Science 332:318-322

> Elliott JA, Irish AE, Reynolds CS (2002) Predicting the spatial dominance of phytoplankton in a light limited and incompletely mixed eutrophic water column using the PROTECH model. Freshw Biol 47:433-440

Ferrari R, Boccaletti G (2004) Eddy-mixed layer interactions in the ocean. Oceanography 17:12-21

Firing E (1991) Acoustic Doppler current profiler measurements and methods. In: WOCE (World Ocean Circulation Experiment) operations manual, Vol 3, Section 1, Part 3: WHP (WOCE Hydrographic Program) operations and methods. WHP Office Report WHPO 91-1, WOCE Report No. 68/91, Woods Hole Oceanographic Institution, Woods Hole, MA

Franks PJS (2001) Turbulence avoidance: an alternative explanation of turbulence-enhanced ingestion rates in the field. Limnol Oceanogr 46:959-963

García-Muñoz C, Lubián LM, García CM, Marrero-Díaz A, Vernet M, Sangrà P (2013) A mesoscale study of phytoplankton assemblages around the South Shetland Islands. Polar Biol 36:1107-1123

> Gargett A, Garner T (2008) Determining Thorpe scales from ship-lowered CTD density profiles. J Atmos Ocean Technol 25:1657-1670

> Goldman JC, McGillicuddy DJ Jr (2003) Effect of large marine diatoms growing at low light on episodic new production. Limnol Oceanogr 48:1176-1182

- Hewes CD, Reiss CS, Kahru M, Mitchell BG, Holm-Hansen O (2008) Control of phytoplankton biomass by dilution and mixing depth in the western Weddell-Scotia Confluence. Mar Ecol Prog Ser 366:15-29

> Hewes CD, Reiss CS, Holm-Hansen O (2009) A quantitative analysis of sources for summertime phytoplankton variability over 18 years in the South Shetland Islands (Antarctica). Deep-Sea Res I 56:1230-1241

Holm-Hansen O, Naganobu M, Kawaguchi S, Kameda T and others (2004) Factors influencing the distribution, biomass, and productivity of phytoplankton in the Scotia Sea and adjoining waters. Deep-Sea Res II 51: 1333-1350

Huisman J, Arrayás M, Ebert U, Sommeijer B (2002) How do sinking phytoplankton species manage to persist? Am Nat 159:245-254

Huisman J, Jonker RR, Zonneveld C, Weissing FJ (1999) Competition for light between phytoplankton species: experimental tests of mechanistic theory. Ecology 80: 211-222 
Huisman J, Sharples J, Stroom JM, Visser PM, Kardinaal WFA, Verspagen JMH, Sommeijer B (2004) Changes in turbulent mixing shift competition for competition for light. Ecology 85:2960-2970

Kang SH, Lee SH (1995) Antarctic phytoplankton assemblage in the western Bransfield-Strait region, February 1993: composition, biomass, and mesoscale distributions. Mar Ecol Prog Ser 129:253-267

Kang SH, Lee SH, Chung KH, Kim D, Park MG (2001) Antarctic phytoplankton assemblages in the marginal ice zone of the northwestern Weddell Sea. J Plankton Res 23:333-352

Kara AB, Rochford PA, Hurlburt HE (2000) An optimal definition for ocean mixed layer depth. J Geophys Res 105: 16803-16821

Kiørboe T (2007) Small-scale turbulence, marine snow formation, and planktivorous feeding. Sci Mar 61 (Suppl 1): 148-158

Klein P, Lapeyre G (2009) The oceanic vertical pump induced by mesoscale and submesocale turbulence. Annu Rev Mar Sci 1:351-375

Kopczynska EE, Ligowsky R (1985) Phytoplankton composition and biomass distribution in the southern Drake Passage, the Bransfield Strait and the adjacent waters of the Weddell Sea in December 1983-January 1984 (BIOMASS-SIBEX). Pol Polar Res 6:65-67

> Kropuenske LR, Mills MM, van Dijken GL, Baile S, Robinson DH, Welschmeyer NA, Arrigo KR (2009) Photophysiology in two major Southern Ocean phytoplankton taxa: photoprotection in Phaeocystis antarctica and Fragilariopsis cylindrus. Limnol Oceanogr 54:1176-1196

> Lavaud J, Strzepek RF, Kroth PG (2007) Photoprotection capacity differs among diatoms: possible consequences on the spatial distribution of diatoms related to fluctuations in the underwater light climate. Limnol Oceanogr 52:1188-1194

> Lozovatsky I, Figueroa M, Roget E, Fernando HJS, Shapovalov S (2005) Observations and scaling of the upper mixed layer in the North Atlantic. J Geophys Res 110: C05013, doi:10.1029/2004JC002708

Mann KH, Lazier JRN (1996) Dynamics of marine ecosystems: Biological-physical interactions in the oceans, 2nd edn. Blackwell Science, Oxford

Mendes CRB, de Souza MS, Garcia VMT, Leal MC, Brotas V, Garcia CAE (2012) Dynamics of phytoplankton communities during late summer around the tip of the Antarctic Peninsula. Deep-Sea Res I 65:1-14

Mendes CRB, Tavano VM, Leal MC, de Souza MS, Brotas V (2013) Shifts in the dominance between diatoms and cryptophytes during three late summers in the Bransfield Strait (Antarctic Peninsula). Polar Biol 36:537-547

Mitchell BG, Holm-Hansen O (1991) Observations and modeling of the Antarctic phytoplankton crop in relation to mixing depth. Deep-Sea Res A 38:981-1007

Nagai T, Tandon A, Rudnick DL (2006) Two-dimensional ageostrophic secondary circulation at ocean fronts due to vertical mixing and large-scale deformation. J Geophys Res 111:C09038, doi:10.1029/2005JC002964

Oakey N, Elliott J (1982) Dissipation within the surface mixed layer. J Phys Oceanogr 12:171-185

> Padman L, Fricker HA, Coleman R, Howard S, Erofeeva L (2002) A new tide model for the Antarctic ice shelves and seas. Ann Glaciol 34:247-254

Pallàs-Sanz E, Johnston TMS, Rudnick DL (2010) Frontal dynamics in a California Current System shallow front: 2. Mesoscale vertical velocity. J Geophys Res 115:C12068, doi:10.1029/2010JC006474

Passarge J, Hol S, Escher M, Huisman J (2006) Competition for nutrients and light: stable coexistence, alternative stable states, or competitive exclusion? Ecol Monogr 76: $57-72$

> Petersen JE, Sanford LP, Michael Kemp P (1998) Coastal plankton responses to turbulent mixing in experimental ecosystems. Mar Ecol Prog Ser 171:23-41

Pollard RT, Regier LA, (1992). Vorticity and vertical circulation at an Oceanic Front. J Phys Oceanogr 22:609-625.

> Richardson K, Beardall J, Raven JA (1983) Adaptation of unicellular algae to irradiances: analysis and strategies. New Phytol 93:157-191

> Sangrà P, Gordo C, Hernádez-Arencibia M, Marrero-Díaz A and others (2011) The Bransfield current system. DeepSea Res I 58:390-402

Savidge DK, Amft JA (2009) Circulation on the West Antarctic Peninsula derived from 6 years of shipboard ADCP transects. Deep-Sea Res I 56:1633-1655

Sverdrup HS (1953) On conditions for vernal blooming of phytoplankton. J Cons Int Explor Mer18:287-295

Teira E, Mouriño-Carballido B, Martínez-García S, Sobrino C, Ameneiro J, Hernández-León S, Vázquez E (2012) Controls of primary production and bacterial carbon metabolism around South Shetland Islands. Deep-Sea Res I 69:70-81

> Thomas LN, Joyce TM (2010) Subduction on the northern and southern Flanks if the Gulf Stream. J Phys Oceanogr 40:429-438

Thomas LN, Tandon A, Mahadevan A (2008) Submesoscale processes and dynamics. In: Hecht MV, Hasumi H (eds) Ocean modeling in an eddying regime. Geophysical Monograph Series Vol 177, American Geophysical Union, Washington, DC, p 17-38

Thompson PA, Pesant S, Waite AM (2007) Contrasting the vertical differences in the phytoplankton biology of a dipole pair of eddies in the south-eastern Indian Ocean. Deep-Sea Res II 54:1003-1028

Thorpe SA (1977) Turbulence and mixing in a Scottish loch. Philos Trans R Soc Lond A 286:125-181

UNESCO (1994) Protocols for the Joint Global Ocean Flux Study (JGOFS) core measurements. IOC Manuals and Guides 29, UNESCO, Paris

> Vaillancourt RD, Sambrotto RN, Green S, Matsuda A (2003) Phytoplankton biomass and photosynthetic competency in the summertime Mertz Glacier region of East Antarctica. Deep-Sea Res II 50:1415-1440

Van de Poll WH, Lagunas M, de Vries T, Visser RJW, Buma AGJ (2011) Non-photochemical quenching of chlorophyll fluorescence and xanthophyll cycle responses after excess PAR and UVR in Chaetoceros brevis, Phaeocystis antarctica and coastal Antarctic phytoplankton. Mar Ecol Prog Ser 426:119-131

> Weissing FJ, Huisman J (1994) Growth and competition in a light gradient. J Theor Biol 168:323-336

- Wolk F, Yamazaki H, Laurent S, Lueck RG (2002) A new free-fall profiler for measuring biophysical microstructure. J Atmos Ocean Technol 19:780-793 